
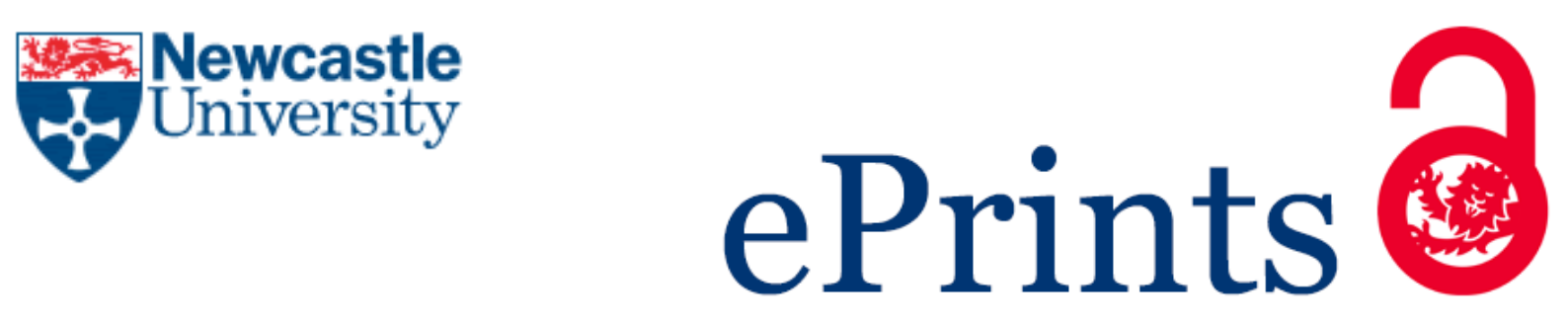

Bamber M, Parry SN. A study of the employment of denial during a complex and unstable crisis involving multiple actors. Journal of Business

Communication 2015. DOI: 10.1177/2329488414525454

Copyright:

(c) The authors, 2014.

DOI link to article:

http://dx.doi.org/10.1177/2329488414525454

Date deposited:

$02 / 04 / 2015$

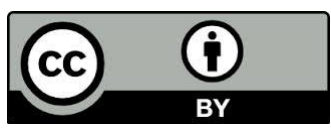

This work is licensed under a Creative Commons Attribution 3.0 Unported License 


\title{
A study of the employment of denial during a complex and unstable crisis involving multiple actors
}

\begin{abstract}
We review the employment of denial through a complex and unstable crisis: the Deepwater Horizon Gulf of Mexico tragedy. Denial is typically viewed as a binary response - 'we did not do this' - with a binary intended outcome - 'and therefore we are not to blame'. We argue that this interpretation is overly simplistic. We found that Transocean and Halliburton executed a strategy consisting of distancing and (counter-)attack to shift blame, whereas BP pursued a strategy dominated by compassion and ingratiation intermixed with carefully employed denial to share blame. This form of blame-sharing is a hybrid of denial and acceptance. BP accepted responsibility but argued that others were responsible too. Our analysis also showed that deny response options were restricted or relaxed dependent upon situational and intertextual context. We found that the tone of the involved parties' releases became significantly more aggressive as the situation developed towards its legal conclusion and as they responded to each other's progressively more hostile releases.
\end{abstract}

Keywords: Crisis Communication; Denial; Press Releases 


\section{Introduction}

We examine the use of denial as a crisis response strategy (CRS) in the aftermath of the Deepwater Horizon (DH) crisis. Denial has many noted benefits for individuals. It can be a form of self-defence (e.g. Levine and Zigler, 1975), impression management (e.g. Leary and Kowalski, 1990; Von Hippel et al., 2005), and sometimes a bridge to self-deception (e.g. Baumeister et al., 1988; Lazarus, 1998). At an organisational level the primary objective of denial is to avert or minimise litigation costs. This alone, however, oversimplifies the strategy. This option provides the opportunity for organisations to restore their image (Benoit, 1997), to take the offensive and move from accused to accuser (Hearit, 1996; Meisenbach, 2010), to capture the moral high ground and help ward off stigmatisation (Mills, 2007), to avert negative valuations (Zuckerman, 1979), and to repair stakeholder goodwill and rebuild employee morale. Whilst 'simple denial' is an outright rejection of responsibility with the aim of absolving the actor of both association and guilt, organisations are known to also employ more sophisticated forms of deny response, such as scapegoating. These secondary options are also considered to be a means of blame shifting (e.g. Benoit, 1997).

We employ Situational Crisis Communication Theory (SCCT) as a theoretical lens through which we examine the responses of key parties to this complex crisis. Advocates of SCCT argue that an entity should respond to a crisis dependent upon the perceived level of organisational responsibility and associated threat to reputational assets (Coombs, 1995; 2006). When a crisis is deemed accidental, the SCCT framework suggests an entity should deny responsibility. Marcus and Goodman (1991) found a spike in effective - value protecting - deny responses especially in the immediate aftermath of an accident. SCCT also urges that once a strategy has been selected, the options (deny, deal and diminish) should not be mixed as this would "erode the effectiveness of the overall response" (Coombs, 2006, 2007: 173). 
Sometimes, however, organisations have response options thrust upon them. Management may wish to follow a certain path but they are prevented from doing so by an external act, event or influence. This is described as communicative avoidance-avoidance conflict (Bavelas et al., 1990). An example might be where management want to apologise to victims but cannot because an apology is tantamount to a full admission of guilt and their shareholder resource stewardship responsibilities prevent this (Tyler, 1997). There was a combination of factors that ensured BP's response strategy would be restricted following the DH tragedy. These included certain questionable judgements and actions prior to the explosion on 20 April, 2010, the acute criticism of decisions taken to control the leak and conduct the subsequent clean-up operation; the surge of negative political, public and media speculation and interest. If BP's management hadn't decided whether or not to pursue a strategy based around simple denial before President Obama's speech on 2 May, 2010, they would be left in no doubt that this was not an option afterwards. "Make no mistake", he declared, "we will fight this spill with everything we've got for as long it takes. We will make BP pay for the damage their company has caused. And we will do whatever's necessary to help the Gulf Coast and its people recover from this tragedy."

Thus, it is fair to say that BP started from the unenviable position of being forced to publicly concede organisational responsibility (Muralidharan et al., 2011) for an apparently preventable tragedy. From that moment forward, achieving absolution from guilt would be impossible. Within the organisation, however, there would have been a strong social, political and economic desire to share some of the blame. It was in their best interests to make certain that the names of the other potentially responsible parties were never far from the public (and legal) eye. Equally, those secondary actors must have been aware that any association with the tragedy could be extremely damaging.

There are occasions, such as this, where denial is not an option because the organisational responsibility appears to be self-evident. Coombs (2007) noted that denial is only effective where 
the stakeholders are convinced, otherwise the effects will be counter-productive. Equally, as Tyler (1997) stated in her study of the much criticised Exxon-Valdez oil spill crisis response, apology might also not be an option because the cost of a full admission of guilt is too great. Therefore, companies are forced into insincere equivocation. Tyler (1997: 55) proposed, with respect to Exxon's response: "it is, of course, entirely possible that no apology... would have sufficed, that some acts are so offensive to those offended that no account could be effective, no matter how convincingly it was performed."

Equivocation is a common factor in organisational crisis response (Tyler, 1997). An 'outright apology' is as rare as an 'outright denial'. Whilst simple denial seeks to shift the blame entirely, an outright apology brings with it the full burden of guilt (e.g. Wagatsuma and Rosett, 1986; Tavuchis, 1991; Tyler, 1997). When selecting a response strategy management must consider questions of morality, but they will also factor in financial implications. All corporate communication will be subject to intense scrutiny during legal proceedings following a crisis (Cooper, 1992) and a simple denial which turns out to lack integrity or validity could do as much harm (maybe more) as an admission of guilt.

There are those who have argued that honesty, openness and candour are paramount to a crisis response and the impact of poor, inappropriate or incomplete corporate communication contributes to negative perceptions and value destruction (e.g. Seeger, 2006). Denial is a strategy which is often believed to conflict with these virtues. This is because, unlike apologies, there have been many occasions where an individual or organisation has denied a charge which has subsequently turned out to have been a true allegation. Despite being a common and credible CRS, many communication theorists have been quick to point out its flaws. Benoit (1995a), for example, noted the potential costs to legitimacy. Sellnow et al. (1998) highlighted denial's divisiveness. With the exception of a small number of studies (e.g. Dionisopolous and Vibbert, 1988; Hearit, 1996; Tyler, 1997; Kim et al., 
2004), the literature lacks a detailed investigation of this CRS and a detailed study of a long-run crisis response. This paper addresses this gap.

We studied press releases from the primary actor - BP; the two secondary actors - Transocean and Halliburton; and the Wall Street Journal (WSJ) spanning over two years. Press releases have been shown to contribute incremental information (Choi, 2012; Choi \& Park, 2011) and that they have a broad reach and appeal (e.g. Maat, 2007). Their main benefit to the issuer is that they are regularly picked up - often copied or paraphrased - by the mainstream media (e.g. Jacobs, 1999; Maat, 2007). On this point, Turk (1986) showed that more press releases are used than are rejected. Whilst it is possible for organisations to sway public opinion through their press releases, it is equally possible for external stakeholders to exert pressure on organisations through the same mechanism (Dunfee, 2008). Therefore we build into our analysis the inter-play of responses.

This paper continues as follows: Section 2 provides a background to the crisis; Section 3 discusses the prior literature and establishes the research questions; Section 4 introduces the research methods; Section 5 presents and discusses the findings; finally, Section 6 provides conclusions and recommendations for future research.

\section{Background}

The DH crisis refers to the explosion aboard the BP leased Transocean rig on the evening of $20^{\text {th }}$ April 2010 and the oil spill that followed. Eleven (11) workers lost their lives and 16 were injured in the original tragedy. The subsequent oil spill has officially been classified as the biggest in history, resulting in approximately 4.9 million barrels of oil being leaked before the well was capped in August 2010 and then deemed "effectively dead" on 19 September by the overseeing senior U.S. federal official, Coast Guard Admiral Thad Allen. 
Not only was the level of organisational responsibility high, but the threat to BP's reputational assets was also severe. The potential costs were acknowledged to be even greater than the sum of the observable elements which were estimated at $\$ 41$ billion. Bob Dudley, BP's CEO, explained in his annual statement that the crisis carried "deep consequences for jobs, businesses, communities, the environment and our industry." He continued, there is a resultant "threat (to) the very existence of the company" (BP, 2010). This, however, did not prevent BP from filing clean audit reports for 2010 and 2011 although the unpredictability of the potential outcome was noted by the auditor.

The level of attribution and the apportionment of blame were critical in every respect for BP and her stakeholders. Investors' concerns were reflected by the fall in the share price. Shares peaked at 645 pence on 20 April 2010, lost almost 16\% over the next few days (543.28 pence on 4 May 2010) and continued to fall to 302.90 pence by 29 June 2010. On 2 August 2012 the price was still languishing at 430 pence.

Other parties were also involved to a greater or lesser degree. Anadarko, for example, held a $25 \%$ stake in the Macondo well. MOEX owned a $10 \%$ stake through a subsidiary, Matsui \& Co. Another firm, Cameron International, manufactured the blowout preventer that was deemed responsible for the failure. All these parties settled with BP before court action was necessary and on each occasion, BP singled out Halliburton and Transocean, urging them to meet their portion of the financial responsibility. BP repeated the same statement six times during the period under review: "The Deepwater Horizon accident was the result of multiple causes, involving multiple parties, including Transocean and Halliburton". Analysts understood that these two entities - Transocean and Halliburton - were different from the others because they had contracts in place with BP that made them more susceptible to financial obligations (WSJ, 17 December, 2011). BP leased the rig from its 
owner Transocean and many of the workers aboard (79 of 126) were Transocean employees.

Halliburton were also contractors responsible for managing and undertaking work.

\section{Literature analysis and research questions}

\subsection{Crisis communication and SCCT: A brief introduction}

There are several reasons why crisis response is an area worthy of separate attention. Crises create a public thirst for information and a pressure on media outlets to satisfy it. Crisis coverage has become progressively more sensationalist partly due to information availability, but also because of the economic pressure brought about by increased competition (Coleman, 1993; Shenk, 1997; Hickey, 1998). The public are increasingly aware of, and interested in, crisis events regardless of their origin, nature or scope. This is due to higher levels of physical and financial mobility, greater global connectivity, and a more diversified level of personal investment and involvement with global operations (Perrow, 1999). Therefore, the threat to an organisation's reputational assets when found guilty of involvement (or even becoming implicated) with a crisis has also intensified.

During a crisis, the media's communication approaches, forms and strategies fundamentally differ from those which are adopted on an average news day (e.g. Li and Izard, 2003). Often this will involve delivering greater volume, swifter immediacy and increased(-ingly) graphic portrayals of events; especially of those moments of crisis or catastrophe (McNaughton-Cassill et al., 2009). In turn, the response to crisis(-es) from the (perceived) responsible organisation(-s) correspondingly adjusts (e.g. Benoit, 1995b; Coombs, 1999a and 1999b; Venette et al., 2003).

Crises elicit emotions from stakeholders and create an attribution effect (e.g. Weiner, 1985, 2006). Denial is a useful strategy to avert and undo attribution because responses are more positive 
towards a party who has been absolved of blame (Weiner, 2006). In the first draft of SCCT (Coombs, 1995), crises were classified into 'types' according to attribution theory parameters. Four broad categories were created based upon the two variables intentionality versus controllability (Coombs, 1995: 455-457). These classifications were supplemented by three additional context specific variables: veracity of the evidence; damage; and performance history. The objective of this exercise is to assess the organisation's level of perceived responsibility for the crisis, gauge the corresponding threat to their reputational assets and identify the CRS that will be most effective in that scenario. SCCT provides a "framework for understanding how to maximise reputational protection for post crisis communication" (Coombs, 2007: 163).

Though SCCT has moved on, the flow charts from Coombs' (1995) original work are still helpful as they facilitate a clear matching process between each form of crisis and an appropriate CRS. The accident decision flowchart (p. 465) suggests the accused should use a combination of mortification and ingratiation strategies assuming that the evidence is 'true', the damage 'major' and the performance history 'positive'. Importantly, however, the flowchart also states that if the evidence was 'false' and the performance history 'positive', then nonexistence or denial strategies would be most appropriate.

Predictions from the SCCT response framework have been shown to hold for short-run crises but for long-run crises, such as this, there is a complex web of intertextual and situational context which is likely to influence the discourse. When parties stand accused, or accuse each other, they are expected to respond. SCCT recommends rebuttal if the evidence is false or refutable. This would

\footnotetext{
${ }^{1}$ The latter is debatable with regard to both BP and Transocean. BP and Transocean management were on board the rig on the day of the accident to celebrate seven years without a safety incident. In addition, BP achieved ninth place in Fortune's 10 Most 'Accountable' Big Companies list (Kimes, 2008) plus they achieved higher than industry average for safety-related incidents. However they had recently suffered a couple of major safety failure incidents, namely the Texas refinery explosion in 2005 and the Alaskan Tundra region spill in 2008. Transocean's history was equally chequered and the WSJ reported their below industry average safety record.
} 
facilitate their distancing, reduce perceived organisational responsibility and thus the potential for reputational damage. Otherwise, they would need to employ the same mortification and ingratiation strategies as if they were responsible. If the accusations are of a transgression, as opposed to an accident, then the accused should again seek to challenge the veracity of the evidence and use denial. Otherwise, the transgression flowchart suggests a combination of mortification and ingratiation.

During their study of the effects of apology versus denial, Kim et al. (2004) established a similar framework. They initially classified events into two categories: those where the outcome is known (i.e. innocence or guilt); and those where it is not. They then sub-divided events in those categories between violation type: those where the initial incidents are competence-related; and those which are integrity-related. By examining participants' reactions they established that some situations were best managed with denial. There are two conclusions from that study which are relevant to this study: first, denial was shown to be a more successful strategy when the outcome was not known, and the initial incident was an integrity violation; second, apology was always a better strategy when there was evidence of guilt, but when there was evidence of innocence it would be better to deny.

The SCCT framework has remained fairly constant over time. With minor exceptions, the SCCT model has been shown to hold (e.g. Fussell et al., 2009; Cooley and Cooley, 2011). One recent major revision reconsidered the crisis types into three clusters: victim; accidental; and preventable (Coombs 2006, 2007). Where the entity is perceived to be a victim of the crisis and the attribution is seen as weak, there is thought to be a mild reputational threat; where the crisis is an accident and the attribution is minimal there is a moderate reputational threat; and where the crisis is deemed preventable and the attribution is strong, there is a severe reputational threat (Coombs, 2007). 
This refined version of SCCT consolidates the notion that there is a link between reputational threat, organisational responsibility and crisis response. The higher the potential crisis responsibility the greater the negative impact on the reputational assets of the organisation (Coombs, 2007). Deny strategies should be used when there is a low level of attribution i.e. where the organisation can be seen as another victim. Diminish strategies should be employed where the attribution is minimal i.e. where the company did not have crisis intentions. Deal response options should be used where the attribution is strong and the crisis was thought to be preventable. In this instance, the threat to reputation is severe (see table 1 ).

Insert table 1 here

\subsection{Denial}

Prior work suggests that denial is a strategy designed to minimise or eliminate litigation risk (e.g. Benoit, 1995a; Sellnow et al., 1998). This interpretation, however, masks the subtlety of the response. Denial can be aggressive or defensive, simple or complex, and carry a host of intended and unintended consequences. As organisational crisis response theory largely emerged from studies of individuals, we shall start there.

Individuals have been known to use denial as a form of self-defence (e.g. Levine and Zigler, 1975) and occasionally, self-deception (e.g. Baumeister et al., 1998; Lazarus, 1998). Levine and Zigler (1975) studied patients' suffering life-threatening illnesses and noted (p.751), "the use of denial to defend oneself against facing the full meaning of impending death, impaired functioning, and disability is a universal phenomenon that has been noted clinically in response to every form of disability and disease." Baumeister et al. (1998) found that individuals are more likely to deny that they face the average level of life risk. In other words, people prefer to believe that they are less 
likely than others to suffer misfortunes. This tendency to unrealistic optimism can lead to increased levels of risk-taking (Burger and Burns, 1988).

Denial is also a mechanism for impression management (e.g. Edwards, 1970; Leary and Kowalski, 1990). Some argue that individuals deny to ward off the stigmatisation associated with perceptions of failure (e.g. Mills, 2007) and to avert negative valuations (Zuckerman, 1979). When an individual uses denial to manage external perceptions, research shows that they should respond quickly. It is widely believed that the timeliness of a deny response is equally important for companies as for individuals (e.g. Williams and Treadaway, 1992; Fearn-Banks, 2011). During the opening moments of a crisis, denial has the greatest positive impact (Marcus and Goodman, 1991).

Organisations will typically deny in order to reduce litigation risk and minimise the associated financial and reputational damage. This does not, however, tell the full story. There are advantages that denial holds over other strategies, including: the ability to take the offensive, to allow the accused to become the accuser, to take the moral high-ground and thus to prevent future stigmatisation (e.g. Hearit, 1996; Meisenbach, 2010). It has been argued that denial is a reformative strategy (Hobbs, 1995) which seeks to eliminate the connection between the entity and the crisis (Coombs, 2012). Hearit (1996: 234), for example, argued that counter-attack was a way of "inverting the direction of the communication and assuming the morally superior role of the accuser". Denial is an impression management method (Allen and Caillouet, 1994). It is a distancing strategy, traditionally asserted to be a means to shift blame.

The literature alerts us to several forms of denial. The first - 'simple denial' - is considered to be an outright refutation (Benoit, 1997). Benoit (1997) also discussed 'shifting the blame' (or 'scapegoating') as a deny response option. In addition, there are several (counter-) attacking deny response options. An entity might accuse or subsequently accuse the accuser with a view to 
eliminating or reducing their perceived responsibility. Coombs $(1999,2012)$ re-categorised this form of denial as kategoria-based apologia. Further examples are discrediting the discreditors (Meisenbach, 2010) and condemning the condemners (Ashforth et al., 2007). Allen and Caillouet (1994: 70) suggested that excuses and justification were post-crisis denial impression management strategies but these have since been re-classified as diminishment strategies (Coombs, 2006). Table 2a summarises the current categorisation of CRS options and table $2 \mathrm{~b}$ briefly outlines the characteristics of each deny response option.

Insert tables $2 \mathrm{a}$ and $2 \mathrm{~b}$ here

It is likely that parallels will be drawn between Exxon's response to the Valdez oil spill and BP's to the $\mathrm{DH}$ tragedy. In many ways they are comparable whilst in some they are not. Regardless of the appropriateness of this comparison, we do note that Exxon's response has been roundly criticised (e.g. Lukaszewski, 1989). The apparent lack of sincerity to their apology and their attempts to shift blame are often highlighted as an example of what not to do. Their apology showed equivocation and strategic ambiguity - presumably to defend against the costs that would follow - and this has been translated by many as a show of corporate arrogance, a reluctance to accept responsibility and a rejection of the need to change. Williams and Treadaway (1992) claimed that Exxon's communications failures stemmed from their ineffective use of burden sharing and scapegoating. They also pointed to a slow initial response as a failure. We reserve judgement however, instead siding with Tyler (1997) who pointed out that Exxon's response might have been unfairly highlighted for criticism. It is probable that Exxon felt the same legal and economic constraints as BP which in turn stifled a full admission of guilt.

In summary, we arrive at two research questions: 
RQ 1: Was denial employed as a CRS by all three involved parties following the DH tragedy? And if so, to what extent?

RQ2: Was there an inter-play of denial between the actors? And if so, were the responses consistent between organisations and over time?

\section{Method}

During the first phase of the analysis we manually collected, identified, classified and coded the responses contained within the press releases from each of the three central actors - BP, Transocean and Halliburton - between CRS. Secondly, we categorised the denial responses thematically by type. The press releases were extracted from each company's websites. To allow us to understand the inter-play between these parties more fully, we investigated whether the denial responses were an exchange occurring between, and because of, one another or a response to an external event or source. Therefore, to achieve a more balanced perspective we also reviewed every WSJ news release containing the words 'Deepwater Horizon' dating from the time of the original explosion. These were located using Factiva.

In line with prior research of this type, we assumed the WSJ was an appropriate proxy for the media as a whole (e.g. Bromiley and Marcus, 1989; Jarrel and Peltzman, 1985). Between the evening of $20^{\text {th }}$ April, 2010 - the time of the explosion - and 1 June, 2012 we identified and analysed 763 press releases as follows: BP - 142; Transocean - 15; Halliburton - 7; and WSJ - 599. In total this amounted to just under 530,000 words, a little over 23,000 sentences and approximately 8,500 paragraphs.

Though the population appears to be weighted towards WSJ releases, it is worth noting that these releases informed both intertextual and situational context. Our coding of these WSJ reports captured only 'new' items. We were aware of prior research (e.g. Jacobs, 1999; Maat, 2007) which 
has found that press releases are regularly adopted by news outlets. Though we found limited evidence of this practice, we were still conscious of the possibility. The majority of the WSJ releases were influenced by external events (e.g. published investigation reports, court proceedings and so forth) and a minority by corporate press releases. There were a handful of occasions where the WSJ plagiarised, but where they did, they tended to reproduce facts and figures.

Manual coding makes it possible to safeguard against double-counting (e.g. BP press release denial paraphrased [or copied and pasted] into a WSJ article, and coded twice). Following the completion of the initial coding exercise we checked every item to ensure that there was no duplication. In the rare instances where the denial appeared either verbatim or paraphrased in the WSJ, we coded the deny response to the corporate press release rather than the WSJ. Rather than plagiarising every press release, we found that instead the WSJ were selective about what they chose to pursue. We also found that they imposed their own perspective on the event to create a story. In total, there were 33 separately identifiable WSJ releases containing unique deny responses. An overview of the media inter-play is provided (table 3).

Insert table 3 here

We coded deny responses thematically. Even though sentences are thought to be a superior unit of measurement (because of their inherent identifiability and objectivity [Ingram and Frazier, 1980], they are a natural unit of written English [Hackston and Milne, 1996] and are thus easier to code [Linsley and Shrives, 2006]) prior work has shown that whichever unit of measurement is used the results are more or less consistent (Hackston and Milne, 1996). We found that most instances of denial were complex and consisted of a statement that was supported by enhancing information. If we were to code each sentence we would lose essential detail that would prevent us from being able to interpret and analyse the text appropriately. 
A pre-coding reading of the press releases appeared to reveal a shift in the tone of the releases over time. Therefore, we revisited this issue once we had completed the initial coding exercise. We categorised each deny response according to a seven-point scale ranging from passive (1), through neutral (4), to aggressive (7). This is a subjective decision-making exercise and therefore we conferred where appropriate. To undertake this coding process effectively, press releases cannot be reviewed either in isolation or without due consideration of their intertextual and situational context. As a general rule, however, we identified examples of passive verbs, such as 'offer', 'learn' and 'assist' and aggressive verbs, for example 'fail' and 'ignore'. Passive adjectives included expressions involving parties being 'close' (as in, 'being near in a relationship') whilst aggressive adjectives include accusations of representations being 'inaccurate'.

According to Smith and Taffler (2000: 627), content analysis research can be categorised into two generic forms: 'form-oriented'; and 'meaning-oriented'. The former relates to measuring the quantity of words whilst the latter focuses on the underlying themes in the observed texts. The latter involves more subjectivity but provides a greater depth of understanding. We sought to measure quantity in the first instance and then interpret in the second. Therefore this study mixes these two forms. Prior work has considered the problems with content analysis as a research method (Beattie and Thomson, 2007; Krippendorff, 2004; Unerman, 2000; Weber, 1990; Milne and Adler, 1999). One common way to mitigate some of the inconsistency and irreproducibility problems is to have a sole coder complete the entire task. This path was chosen. We also had a second coder undertake the exercise and results of the inter-coder reliability tests show that kappa coefficients were in excess of $\mathrm{K}=0.85$ (with a range $\mathrm{k}=0.75$ through $\mathrm{K}=0.97$ ). Thus the findings were deemed robust. Any discrepancies and disagreements were discussed and amended where appropriate. 
Unlike Transocean and Halliburton's press releases, it was clear that denial did not dominate BP's response but was, nevertheless, present. For completeness and precision, we undertook a final phase of detailed analysis. We revisited the press releases and this time coded paragraphs (rather than themes) to their applicable CRS (where originally we had coded by theme). In total, BP released 704 paragraphs related to the crisis between 20 April, 2010 and 1 June, 2012. Again, to address any potential problems with reliability, the coding process was also undertaken by a second person. Kappa coefficients for inter-coder reliability were $\mathrm{k}=0.85$. Thus, the sensitivity analysis indicates that the results of the coding exercise are robust.

\section{Results}

\subsection{General comments}

Transocean and Halliburton's responses were dominated by denial. They shared two similarities: first, when challenged, they provided clarificatory counter-information to deny the veracity of any evidence laid against them; and second, they employed attack or counter-attack. BP's releases were dominated by deal (91.8\%) with some denial (7.5\%; 41 items) whilst diminishment was rarely evident (0.7\%) (table 4).

Insert table 4 here

In total there were 86 separately identifiable denial themes in the press releases of the three entities (see table 5). Responses were clustered around key events. The initial phase covered the first ten days after the explosion where there were 11 combined instances of denial - predominantly scapegoating by BP and (counter-)attack from Transocean. The second phase related to the oil spill and attempts to stop the leak (39 deny responses). There was then a period of silence punctuated by 
the occasional attack and riposte. Finally there was a third phase which commenced exactly a year after the explosion triggered by the approaching legal proceedings and their financial implications. In the two months between 17 October and 17 December, 2011 there were 18 instances of deny responses mostly consisting of attack and accuse the accuser (12).

Insert table 5 here

As prior research predicted, each denial was prompt and was followed swiftly with a riposte where appropriate (e.g. Williams and Treadaway, 1992; Fearn-Banks, 2011; Marcus and Goodman, 1991). We found that BP initially adopted a passive scapegoating strategy which later became aggressive, whilst Transocean and Halliburton started on the front foot and finished even stronger. We explore this further below.

\subsection{BP's response and their provocation of inter-play}

Despite prior theoretical and empirical literature suggesting their likely absence, there were four instances of 'simple denial' whilst the remainder of the 41 deny responses were fairly evenly balanced between scapegoating (17) and attack (20). Finding evidence of 'simple denial' was surprising given the context. On closer examination, however, we found that these were all made in response to media reports. This fits with Kim et al.'s (2004) denial matrix framework predictions. BP denied outright those challenges to their integrity where there was no evidence of wrong-doing (three of the four instances) and challenges to their competence where irrefutable evidence existed to the contrary (one).

The remainder of BP's denial responses can be ordered chronologically into two phases: initially they employed defensive strategies, predominately, scapegoating; whilst later they went on the offensive 
with attack and counter-attack. The case against BP seemed indisputable (Muralidharan et al., 2011) and therefore simple denial was not an option. Ingratiation and compassion, however, were intermixed with scapegoating. This scapegoating strategy was not intended to shift the blame but it did allow them to introduce new information that challenged other parties' integrity and competence. Implicating others allows a wider distribution of organisational responsibility and reduces the threat to the reputational assets of a stand-alone guilty party.

This strategy can be seen as a hybrid of denial and crisis acceptance. The hybrid nature exists since BP's management were neither denying responsibility nor were they accepting it fully. Instead, the response sought to serve two functions: to act as a form of distancing; and, to implicate other organisations in order to share the blame. In other words, the message can be translated as: 'we are not the only ones to blame so please refrain from holding us so strongly to account'. This study is the first to present evidence of this hybrid strategy, but it is unlikely that its employment is unique. Even if BP were the first, it is probable that we will see more companies taking responsibility (and benefitting from the associated long-term reputational and financial gains) for a crisis alongside sharing the blame (to attempt to minimise short-term reputational and financial losses) with suppliers - directly or indirectly - who contributed to the crisis.

How did BP exact their scapegoating blame-sharing strategy? Whilst the mainstream media reported on the preventable tragedy that was the 'BP oil spill', BP's management were reporting on the "Transocean Deepwater Horizon drilling rig" "accident". On six separate occasions the company's press releases repeated the same phrase: "The Deepwater Horizon accident was the result of multiple causes, involving multiple parties, including Transocean and Halliburton". BP systematically used Transocean's status as the rig's owner to bring their name into the frame (e.g. 21, 22, 24, 25, 26, 28 and 29 April, 2010) whilst referring to themselves as "lease operator". The early press releases declared that they were: "working closely with Transocean", "offer[ing] full support to

\footnotetext{
${ }^{2}$ On five separate occasions during the week immediately following the accident.
} 
drilling contractor Transocean Ltd. and its employees after fire caused Transocean's semisubmersible drilling rig Deepwater Horizon to be evacuated overnight", and "assisting Transocean" employees in the aftermath, investigation and clean-up.

One of the striking features of BP's response strategy was the shift from this passive scapegoating approach to an aggressive attacking one. The response of the secondary parties was to adjust the tone of their releases accordingly. Transocean also opened their account with reference to their "support" role, but they were far more forceful in asserting that they were not to blame. Instead, they placed themselves as victim and burden bearer (April 22, 23 and 26, 2010). In fact, neither Halliburton nor Transocean at any stage acknowledged any guilt.

The combined number of instances of scapegoating during the first three months following the incident was 16; 14 of which were BP and 10 occurred before the 30 April, 2010 (i.e. within 10 days of the explosion). This is in contrast to the period October to December 2011, in the build-up to the anticipated court date, where there were 12 instances of outright attack (and only 2 instances of scapegoating).

We appreciate that language makes it possible for there to be 'aggressive scapegoating' as much as 'passive attack' and therefore relying on counting the use of response types is not sufficient. Instead, we analysed the press releases of the three parties over the duration of the crisis response using a seven-point scale ranging from passive (1), through neutral (4) to aggressive (7). The findings show the same pattern. Responses became significantly more aggressive over time (figure 1). BP's response began passively but moved towards out-and-out aggression. The other parties' press releases began more aggressively than $\mathrm{BP}^{\prime} \mathrm{s}$, and intensified in tone over time to match those of the primary protagonist. 
The media translated Transocean's responses as a reaction against BP's (over-) aggression. On 9 December 2011 the WSJ reported one senior analyst's view that "the [Obama] administration wants the parties to settle, and probably sees BP's more aggressive stance [against the other parties] as less conducive to settlement." Around that time there were additional citations levied against BP and the analyst thought this was the administration "sending a reminder to BP to get back in its box".

Exactly one year after the initial explosion, BP filed law suits against the other actors ${ }^{3}$. This marked the beginning of communications hostilities which would be exacerbated over the coming days and months by accusations, rebuttals and counter-accusations. Other key events also intensified the situation and stimulated attacks, including: Transocean and Halliburton filed for early summary judgements; Transocean and Halliburton were subsequently granted partial indemnification; and the final court dates for settlements approached. The subtle and defensive blame-sharing strategies which were evident in the immediate aftermath of the explosion gave way to blame-shifting as a set of new aggressive messages emerged.

On the day Transocean filed for indemnification (1 November, 2011), Nick Deeming, Senior Vice President and General Counsel of Transocean stated: “BP's posture in this matter is not only offensive to the thousands of men and women who work together at Transocean, but it constitutes a direct threat to the sanctity of contracts and to the economic underpinnings of an industry that employs hundreds of thousands of people in the United States alone". On 2 November, 2011 BP announced: "letting Transocean off the hook for cleanup costs would be inconsistent with the law and sound public policy". A BP spokesman added: "to enforce the indemnification would be to allow Transocean to escape the consequences of their actions and avoid meeting its obligations in the Gulf." After Cameron came to a settlement on 16 December, 2011 BP's press release stated:

\footnotetext{
${ }^{3}$ BP filed suits against Transocean, Halliburton and Cameron worth \$40bn on April 21, 2011.
} 
"Unfortunately, other companies persist in refusing to accept responsibility for their roles in the accident"

Halliburton were not spared from BP's changed strategy. BP's releases sought to cast doubt on Halliburton's integrity and competence, citing potential fraud and negligence. On 31 January, 2012 for example, BP announced: "All official investigations have concluded that Halliburton played a causal role in the accident... Moreover, the court determined that if Halliburton is found to have committed fraud, then [their] indemnity could be void." Halliburton responded thus: "BP is attempting to divert attention from its poor decisions and practices by criticizing the work and reputation of Halliburton."

Our findings suggest that there might be a weakness in the current deny response option categorisation system. The observable shift in tone and type of denial response gives rise to two questions: 1. Is the SCCT framework flexible enough to provide a single strategy to cope with longrun complex crises?; and, 2 . Would it be more appropriate to sub-categorise denial responses between blame-sharing and blame-shifting rather than the existing categorisation of naive and sophisticated?

\subsection{Transocean and Halliburton's denial response}

BP's releases were dominated by a mixture of compassion (71.4\%) and ingratiation (16.2\%) (deal). BP was offered up to the public as a scapegoat and, for the most part, journalists seemed content to accept this situation. There remained throughout, however, a level of balance to the media's coverage. The WSJ reported issues, concerns and grievances against all parties, not just BP, which arose from completed and ongoing investigations, court cases, speeches and other events including each other's press releases. Transocean and Halliburton were singled out as the main secondary 
actors because of their contractual position. Transocean released a number of compassionate messages during the early stages but the overarching strategy dominating both Halliburton and their press releases was denial, especially simple denial (Transocean: 15 thematic recurrences; Halliburton: 7) and (counter-) attack (Transocean: 13; Halliburton: 6).

Transocean and Halliburton's deny responses appear to share two common objectives: first, to identify and expose evidence which ran contrary to any accusations made against them; and second, to characterise their company and employees as victims. Their mutual objectives during this response inter-play appear to have been: to distance themselves; and to ensure none of the organisational responsibility heaped upon BP was transferred to them. Interestingly, we found no evidence of either of the secondary actors accusing each other.

Advocates of SCCT would have predicted these organisations' response. Denial is a distancing strategy (Benoit, 1995b, 1997; Coombs, 2006), intended to minimise litigation risk (Tyler, 1997) and can be employed where the perceived organisational responsibility is low because the evidence presented is either false or refutable. Denial pushes the burden of proof from accused to accuser (Hearit, 1996). The relatively aggressive opening position and increasingly aggressive ripostes also tie in with the theoretical framework. By taking the offensive and casting themselves in the role of victim, the management teams sought to take the moral high ground, prevent stigmatisation (e.g. Hearit, 1996; Meisenbach, 2010; Mills, 2007) and generate internal savings, for example, preservation of self-esteem (for the entity and its employees).

In addition, Kim et al. (2004) argued that denial is most effective under two conditions: first, the accusations are challenges to integrity but the outcome is unknown; or second, the challenges to either competence or integrity are false and the evidence is refutable. Indeed, Transocean and Halliburton's responses conform to this framework. There was only one occasion where a chink was 
revealed in Halliburton's armour. They were presented with evidence, which on that occasion was provided under oath, detailing fraudulent statements. This story was picked up by BP and the media. Nevertheless, the company continued to pursue their denial strategy and responded thus (1 February, 2012): "Halliburton deny the accusations of fraudulent behaviour made by BP"; and later, BP's claims are "without merit... we look forward to contesting their motion in court."

Transocean maintained a consistent communication strategy throughout. When competency-based concerns were raised, their response was timely and characterised by rebuttal and provision of counter-evidence. An early investigation into the incident, for example, highlighted some of their potential failings. In reply, (between 22 May, 2010 and 28 May, 2010) the company issued eight strong instances of denial, five of which were concentrated in one release. Transocean addressed each accusation made against them with a deny response, and accompanied many with a counterattack. When challenged, the company provided incremental clarificatory information and supplementary technical explanations of events and processes.

On $8^{\text {th }}$ September (2010) BP released their investigation report. Transocean and Halliburton held a conference call and released statements the following day but it was Transocean's response to the WSJ on that day which best summarises their mutual position. The WSJ reported that these two companies reject the findings of BP's Deepwater Horizon report. Transocean's spokesperson said, the "UK company had all the final calls and should be held responsible for the billions of dollars in damage caused by the disaster, which killed 11."

During 2011 ( $22^{\text {nd }}$ June), a press release accompanied the Transocean investigation report. This contained seven separate deny responses: two cases of simple denial (against accusations made by 
BP); four accusations; and one condemnation of the condemner ${ }^{4}$. On 1 November, 2011 as the court hearing dates approached, Transocean filed a motion for a summary judgement and issued a press release that contained a combination of attack (3), shifting the blame (1), denial (1) and condemning the condemner (1).

The challenges made to Transocean were not only competence-related, they were also integrityrelated. Court appearances made by Transocean employees led BP and the media to question Transocean's safety and maintenance policies as well as the potential mis-management of the rig. Transocean's response was, again, denial. WSJ reported on 10 May, 2010 that there was a disagreement between management teams from BP and Transocean on board the $\mathrm{DH}$ rig in the moments leading up to the explosion. Transocean immediately denied and dismissed these accusations in a press release the following day. Two further accusations from former employees over safety concerns were reported in the WSJ during July 2010. Transocean simply denied both at their first opportunity. In the second of these reported cases, an ex-employee told the courts that the warning alarm was disabled to allow crew to sleep through the night. Transocean replied promptly and strongly, saying: "Transocean denies Mr Williams claims, and witness testimonies at times have been contradictory".

As Transocean's' crisis can be seen to be two parts - challenges to competence and integrity - so too was Halliburton's. On the one hand, they were accused of making on-board technical errors including incomplete cementing works and a failure to adequately interpret foam stability testing results. On the other hand, attention was also drawn to issues of managerial wrongdoing and

\footnotetext{
${ }^{4}$ The classification 'condemn the condemner' is subjective. We categorised both this item and another later item as such because they shared a specific set of characteristics. In these comments, an accusation was refuted with a counter-accusation being made against the initiating party, of the same type, but with an added emotional angle, rather than a purely technical one. In many ways, the response was akin to: "you have no right to criticise us; you have done worse."
} 
making fraudulent statements. Both challenges were consistently met with the same response prompt denial.

The major difference between Halliburton's response strategy and that of the other two parties is their lack of willingness to initiate. We found that BP, and to a lesser extent Transocean, were proactive in their responses, whereas Halliburton were reactive. This is surprising given the arguments about denial and distancing. The reason might lie within Tyler's (1997) question of whether there is an alternative to apology (and denial) that does not exacerbate legal complications. Maybe Halliburton's silence, or a non-response, is the solution for a secondary party caught up in a complex multi-party scenario?

On 11 May, 2010, in response to accusations from BP of failing to complete their work appropriately, Halliburton issued a press release that stated "the well owner's representative... has the ultimate authority for decisions on how and when various activities are conducted." When BP's investigation report was released (8 September, 2010), Halliburton's message was clear; they thought the report was biased and did not represent an accurate or faithful rendering of events. They denied its validity and called the author's integrity into question. They stated that there were "a number of substantial omissions and inaccuracies." During their response to this report, Halliburton employed simple denial seven separate times.

Later challenges to their competency were responded to similarly. On three occasions they denied the authority and substance of evidence contained within news items (WSJ). A further three times they denied accusations made against them by BP on the grounds of inaccuracy and incompleteness. Finally, they denied allegations and evidence contained within the National Commission report, claiming the writers "selectively omitted information provided to it by Halliburton" saying furthermore that it was a misrepresentation of the facts. 


\section{Conclusion}

As the theoretical framework predicted, both Transocean and Halliburton's press releases were dominated by denial whilst BP's consisted largely of deal. SCCT suggests that a successful denial strategy will cast doubt over the veracity of evidence in order to prevent false accusations manifesting themselves. This is a distancing strategy, the objective of which is to minimise litigation risk and the threat to reputational assets by reducing perceived organisational responsibility. Transocean and Halliburton carefully employed a strategy which sought to cast themselves in the role of victim to free themselves and their employees from not just financial burden, but also guilt and stigmatisation. We also found evidence to confirm Kim et al.'s (2004) predictions that denial would be best employed where integrity was challenged and the outcome is unknown, and where competence was falsely challenged and the evidence was false or refutable.

In the early phases of the crisis, BP's crisis response options were restricted. The strength and depth of negative feeling against them alongside the apparent veracity of the printed, spoken and photographic evidence ensured they were the perfect scapegoat. Nevertheless, alongside a strategy dominated by deal, BP also used deny responses wherever possible. The primary difference between the denial strategy BP employed and that of the other parties was the use of scapegoating as a means to share blame rather than shift blame. This strategy is unique and we would urge future researchers to investigate the use and impact of this hybrid response - denial plus acceptance through other crises.

Crisis communication research has tended to view denial as a binary response with a binary intended outcome. The response being: 'we did not do this'; the intended outcome being: 'and therefore we are not to blame'. We argue that BP's strategy was different. Their management team 
used scapegoating as a means to implicate others, to lessen their perceived level of organisational responsibility and to influence a reduction in litigation risk and future costs. The message being put across appears to be: "we were responsible, but others were too. Therefore do not judge us so harshly".

SCCT categorises deny response options between naive and sophisticated. Our findings show that corporate communication shifts in tone and type dependent upon the situational and intertextual context rather than according to a need for sophistication. These shifts appear to be deliberate. Therefore we propose an extension to the SCCT framework. We suggest future researchers consider denial, and its effectiveness, in terms of context and intention i.e. blame-shifting and blame-sharing; rather than type i.e. naive and sophisticated.

All three companies used their press releases to reveal new - often contrasting, contradictory or confounding - information to contest accusations made against them. They sought to correct (what they perceived to be) misinformation and when they were attacked, they promptly denied and often counter-attacked. We found that BP, and to a lesser extent Transocean, were proactive in their deny responses whilst Halliburton was reactive. We suggest that the latter's silence could be an effective alternative to denial or apology in a multi-party scenario such as this. Crisis communication tends to ignore this (non-)response.

This study is the first to examine CRS' during a crisis which is prolonged, unstable and complex. Prior work has called for a study of a long-run crisis to gauge whether response strategies are stable. We found that BP's strategy was dominated by deal responses but was also inter-mixed with denial and diminishment. Transocean's was mostly denial with a small element of deal. Halliburton's was essentially denial. We found a clear and marked shift in the tone of all parties' responses as the crisis developed towards its (legal and financial) conclusion. We show that in the first few weeks following 
the explosion and until the well was capped the tone was broadly passive or neutral. As soon as BP, however, took a more aggressive line legalistically, they also took a more aggressive line rhetorically. They filed suits against Transocean and Halliburton one year after the explosion and this was the signal for the commencement of hostilities. The deny responses became more forceful. In the early phases, responses were mainly passive and blame-sharing. In the later stages, this gave way to blame-shifting, attack and counter-attack. This was obvious to all interested stakeholders and the shift in tone was noted by analysts, the media and the administration.

We suggest that denial should be considered in more detail by future researchers. An interesting study could consider surveying employees and stakeholders of an organisation which has pursued a denial strategy to gauge their morale and goodwill respectively. We urge crisis communication researchers to consider whether silence, or non-response, as a response and is an appropriate and effective alternative to apology or denial. Further work should seek to assess the effectiveness of Kim et al.'s (2004) denial/apology, competence/integrity, guilt/innocence matrix in a corporate setting. It would also be worth exploring further whether our finding - that response tone shifts towards aggression over time - is generalisable; and why this might be the case. 


\section{References}

Allen, M. W., \& Caillouet, R. H. (1994). Legitimation endeavors, impression management strategies used by an organization in crisis. Communication Monographs, 61, 44-62.

Ashforth, B. E., Kreiner, G. E., Clark, M. A., \& Fugate, M. (2007). Normalizing dirty work:

Managerial tactics for countering occupational taint. Academy of Management Journal, 50, 149-174.

Baumeister, R. F., Dale, K. \& Sommer, K. L. (1998). Freudian Defense Mechanisms and Empirical

Findings in Modern Social Psychology: Reaction Formation, Projection, Displacement, Undoing, Isolation, Sublimation, and Denial. Journal of Personality, 66(6), 1081-1124.

Bavelas, J. B., Black, A., Chovil, N., \& Mullett, J. (1990). Equivocal communication. Newbury Park, CA: Sage.

Beattie, V. \& Thomson, S.J. (2007). Lifting the lid on the use of content analysis to investigate intellectual capital disclosures. Accounting Forum, 31(2), 129-163.

Benoit, W. L. (1995a). Sears' repair of its auto service image: Image restoration discourse in the corporate sector. Communication Studies, 46, 89-105.

Benoit, W. L. (1995b). Accounts, excuses, and apologies: A theory of image restoration strategies. Albany, NY: State University of New York Press.

Benoit, W. L. (1997). Image repair discourse and crisis communication. Public Relations Review, 23, $177-186$.

BP plc (2010). Annual Report and financial statements.

Bromiley, P. \& Marcus, A. (1989). The deterrent to dubious corporate behavior: Profitability, probability and safety recalls. Strategic Management Journal, 10, 233-250.

Burger, J.M. and Burns, L. (1988). The Illusion of Unique Invulnerability and the Use of Effective Contraception. Personality and Social Psychology Bulletin, 14(2), 264-270.

Choi, J. (2012). A content analysis of BP's press releases dealing with crisis. Public Relations Review, 38(3), 422-429. 
Choi, J., \& Park, S. (2011). Influence of advertising on acceptance of press releases. Public Relations Review, 37, 106-108.

Coleman, C-L. (1993). The Influence of Mass Media and Interpersonal Communication on Societal and Personal Risk Judgments. Communication Research August, 20, 611-628.

Cooley, S.C. \& Cooley, A.B. (2011). An examination of the situational crisis communication theory through the general motors bankruptcy. Journal of Media and Communication Studies, 3(6), 203211.

Coombs, W. T. (1995). Choosing the right words: The development of guidelines for the selection of the "appropriate" crisis-response strategies. Management Communication Quarterly, 8, 447-476. Coombs, W. T. (1999a). Information and compassion in crisis response: A test of their effects. Journal of Public Relations Research, 11, 121-142.

Coombs, W. T. (1999b). Ongoing crisis communication: Planning, managing, and responding. Thousand Oaks, CA: Sage.

Coombs WT (2006). The prospective powers of crisis response strategies: Managing reputation assets during a crisis. Journal of Promotion and Management, 12(3-4), 241-260.

Coombs, W. T. (2007). Protecting organization reputations during a crisis: The development and application of situational crisis communication theory. Corporate Reputation Review, 10(3), 163177.

Coombs, W. T. (2012). Ongoing crisis communication ( $3^{\text {rd }}$ ed). Thousand Oaks, CA: Sage.

Cooper, D. A. (1992). CEO must weigh legal and public relations approaches. Public Relations Journal, 48(40), 39-40.

Dionisopolous, G.N. \& Vibbert, S.L. (1988). CBS versus mobil oil: charges of creative bookkeeping, in: H.R. Ryan (Ed.), Oratorical Encounters: Selected Studies and Sources of 20th Century Political Accusation and Apologies, Greenwood, Westport, CT, pp. 214-252. 
Dunfee, T. W (2008). Stakeholder theory: Managing corporate social responsibility in a multiple actor context. In A. Crane, A. McWilliams, D. Matten, J. Moon \& D. S. Siegel (Eds.), The Oxford Handbook of Corporate Social Responsibility (pp. 346-362). Oxford: Oxford University Press. Fearn-Banks, K. (2011). Crisis communications: A casebook approach. New York: Routledge. Fussell Sisco, H., Collins, E.L. \& Zoch, L.M. (2010). Through the looking glass: A decade of Red Cross crisis response and situational crisis communication theory. Public Relations Review, 36(1), 21-27. Hackston, D. and Milne, M.J. (1996). Some determinants of social and environmental disclosures in New Zealand companies, Accounting, Auditing and Accountability Journal, 9(1), 77-108.

Hearit, K. M. (1996). The use of counter-attack in apologetic public relations crises: The case of General Motors vs. Dateline NBC. Public Relations Review, 22, 233-248.

Hickey, N. (1998), Money lust. Columbia Journalism Review, July/August, 28-36.

Hobbs, J. D. (1995). Treachery by any other name: A case study of the Toshiba public relations crisis. Management Communication Quarterly, 8, 232-246.

Ingram, R.W., \& Frazier, K. (1980). Environmental performance and corporate disclosure. Journal of Accounting Research, 18(4), 614-622.

Jacobs, G. (1999). Self-reference in press releases. Journal of Pragmatics, 31(2), 219-242.

Jarrel, G. \& Peltzman, S. (1985). The impact of product recalls on the wealth of sellers. Journal of Political Economy, 93, 512-536.

Kim, P. H., Ferrin, D. L., Cooper, C. D., \& Dirks, K. T. (2004). Removing the shadow of suspicion: The effects of apology versus denial for repairing competence-versus integrity-based trust violations. Journal of applied psychology, 89(1), 104-118.

Krippendorff, K. (2004). Content analysis: An introduction to its methodology. 2nd edition, Sage Publications, Beverley Hills.

Lazarus, R.S. (1998). Fifty years of the research and theory of R. S. Lazarus: An analysis of historical and perennial issues. Mahwah, NJ: Erlbaum. 
Leary, M. R., \& Kowalski, R. M. (1990). Impression management: A literature review and two component model. Psychological Bulletin, 107, 34-47.

Levine, J. \& Zigler, E. (1975). Denial and self-image in stroke, lung cancer, and heart disease patients. Journal of Consulting and Clinical Psychology, 43(6), 751-757.

Li, X. \& Izard, R. (2003). From an Academic: 9/11 Attack Coverage Reveals Similarities, Differences. Newspaper Research Journal, 24(1), 204-219.

Linsley, P.M. \& Shrives, P.J. (2006). Risk reporting: a study of risk disclosure in the annual reports of UK companies. The British Accounting Review, 38(4), 387-404.

Lukaszewski, J. E. (1989). How vulnerable are you? Lessons from Valdez. Public Relations Quarterly, Fall, 5-6.

Maat, H. P. (2007). How promotional language in press releases is dealt with by journalists:

Genre mixing or genre conflict. Journal of Business Communication, 44, 59-95.

Marcus, A.A. \& Goodman, R.S. (1991). Victims and shareholders: The dilemma of presenting corporate policy during a crisis. Academy of Management Journal, 34, 281-305.

McNaughton-Cassill, M.E., Novian, D.E., Holmes, T.L. \& Smith, T.L. (2009). Emotional Stress and Coping in Response to Television News Coverage of the 9/11 Terrorist Attacks. Journal of Media Psychology, 14(1), 1-30.

Meisenbach, R.J. (2010). Stigma Management Communication: A Theory and Agenda for Applied Research on How Individuals Manage Moments of Stigmatized Identity. Journal of Applied Communication Research, 38(3), 268-292.

Mills, M. (2007). Without trucks we'd be naked, hungry \& homeless. In S. K. Drew, M. Mills, \& B. M. Gassaway (Eds.), Dirty work: The social construction of taint (pp. 77-93). Waco, TX: Baylor University Press.

Milne, M.J. \& Adler, R.W. (1999). Exploring the reliability of social and environmental disclosures content analysis. Accounting, Auditing and Accountability Journal, 12(2), 237-256. 
Muralidharan, S., Dillistone, K. and Shin, J-H. (2011). The Gulf Coast oil spill: Extending the theory of image restoration discourse to the realm of social media and beyond petroleum. Public Relations Review, 37(3), 226-232.

Perrow, C. (1999). Organizing to Reduce the Vulnerabilities of Complexity. Journal of Contingencies and Crisis Management, 7(3), 150-155.

Seeger, M.W. (2006). Best Practices in Crisis Communication: An Expert Panel Process. Journal of Applied Communication Research, 34(3), 232-244.

Sellnow, T.L., Ulmer, R.R. \& Snider, M. (1998). The compatibility of corrective action in organizational crisis communication. Communication Quarterly, 46(1), 60-74.

Shenk, D. (1997). Data Smog. New York: HarperCollins Publishers.

Smith, M., \& Taffler, R. J. (2000). The chairman's statement: A content analysis of discretionary narrative disclosures. Accounting, Auditing and Accountability Journal, 13(5), 624-647.

Tavuchis, N. (1991). Mea Culpa: A Sociology of Apology and Reconciliation, Stanford, CA. Stanford University Press.

Turk, J. V. (1986). Public relations influence on the news. Newspaper Research Journal, $7(4), 15-26$.

Tyler, L. (1997). Liability Means Never being Able to Say You're Sorry Corporate Guilt, Legal Constraints, and Defensiveness in Corporate Communication. Management Communication Quarterly, 11(1), 51-73.

Unerman, J. (2000). Methodological issues: reflections on quantification in corporate social reporting content analysis. Accounting, Auditing and Accountability Journal, 13(5), 667-680.

Venette, S. J., Sellnow, T. L., \& Lang, P. A. (2003). Metanarration's role in restructuring perceptions of crisis: NHTSA's failure in the Ford-Firestone crisis. Journal of Business Communication, 40, 219-237. Von Hippel, W., Von Hippel, C., Conway, L., Preacher, K. J., Schooler, J. W., \& Radvansky, G. A. (2005). Coping with stereotype threat: Denial as an impression management strategy. Journal of personality and social psychology, 89, 22-35. 
Wagatsuma, H., \& Rosett, A. (1986). The implications of apology: Law and culture in Japan and the United States. Law and Society Review, 461-498.

Weiner, B. (1985). An attributional theory of achievement motivation and emotion. Psychology Review, 92, 548-573.

Weiner, B. (2006). Social Motivation, Justice, and the Moral Emotions: An Attributional Approach. Lawrence Erlbaum Associates, Inc., Mahwah, NJ.

Williams, D. E. \& Treadaway, G. (1992). Exxon and the Valdez accident: A failure in crisis communication. Communication Studies, 43, 56-64.

Zuckerman, M. (1979). Attribution of success and failure revisited, or: The motivational bias is alive and well in attribution theory. Journal of Personality, 47, 245-287. 
Table 1: SCCT (Coombs, 2006: 244 and 248)

\begin{tabular}{|c|c|c|}
\hline Phase 1: Crisis cluster & & $\begin{array}{l}\text { Phase 2: Crisis response } \\
\text { strategies }\end{array}$ \\
\hline Clusters & Examples & \\
\hline Victim cluster: & \multirow{2}{*}{$\begin{array}{l}\text { Natural disasters, rumours, } \\
\text { workplace violence, product } \\
\text { tampering / malevolence }\end{array}$} & Deny response options \\
\hline $\begin{array}{l}\text { i.e. the company is the } \\
\text { victim of the crisis as well }\end{array}$ & & \\
\hline Accidental cluster: & \multirow{2}{*}{$\begin{array}{l}\text { Challenges, megadamage, technical } \\
\text { breakdown accidents and recalls }\end{array}$} & Diminish response options \\
\hline $\begin{array}{l}\text { i.e. company does not have } \\
\text { crisis intentions in its actions }\end{array}$ & & \\
\hline Preventable cluster: & \multirow{2}{*}{$\begin{array}{l}\text { Human breakdown accidents and } \\
\text { recalls, organisational misdeed } \\
\text { with or without injuries, } \\
\text { management misconduct. }\end{array}$} & Deal response options \\
\hline $\begin{array}{l}\text { i.e. a company intentionally } \\
\text { places people at risk, takes } \\
\text { inappropriate actions or } \\
\text { violates laws / regulations. }\end{array}$ & & \\
\hline
\end{tabular}


Table 2a: Crisis response strategies by response option

Deny response options

Naive Sophisticated

Simple denial Shifting the blame / scapegoating

Attack / attacking the accuser/ discrediting the discreditors /

condemning the condemners

Diminish response options

Excuses: Denial of intention / denial of volition / denial of agency

Justification: Denial of injury and victim

Knowledge misrepresentation

Deal response options

Ingratiation

Concern

Compassion

Regret

Apology

Table 2b: Deny response options and their characteristics

\begin{tabular}{|l|l|}
\hline Deny response option & Characteristics \\
\hline Simple denial & We did not do this \\
\hline Scapegoating & This was done by someone else \\
\hline Attack & $\begin{array}{l}\text { You did this } \\
\ldots \text { and therefore it cannot have been us }\end{array}$ \\
\hline Accuse the accuser & You said we did this, but actually it was you \\
\hline Condemn the condemner & $\begin{array}{l}\text { You said we did this, but you did this (or that) } \\
\ldots \text { and that was worse }\end{array}$ \\
\hline Discrediting the discreditors & $\begin{array}{l}\text { You said we did this, but you have no right to } \\
\text { make this accusation because... }\end{array}$ \\
\hline
\end{tabular}


Table 3: WSJ releases containing deny response options and the interplay with other parties

Media report resulting from $\mathrm{BP} /$ Transocean/Halliburton press

Number Percentage

release

Of these:

- Proportion of positive press releases reflected back onto originator and turned into a negative media portrayal

- Proportion of press releases where tone maintained in media

Media report as a result of other party response (Anadarko, Cameron)

Response from accused party to media report (either within the media report or through separate disclosure) 
Table 4: BP's crisis response (paragraphs)

\section{Deny response options}

Simple denial

Total \%age

Shifting the blame / scapegoating

Attack / attacking the accuser/ discrediting the discreditors / condemning the condemners

\begin{tabular}{rr}
5 & $0.7 \%$ \\
24 & $3.4 \%$ \\
& \\
24 & $3.4 \%$ \\
53 & $7.5 \%$ \\
& \\
5 & $0.7 \%$ \\
0 & $0.0 \%$ \\
0 & $0.0 \%$ \\
5 & $0.7 \%$ \\
& \\
114 & $16.2 \%$ \\
24 & $3.4 \%$ \\
503 & $71.4 \%$ \\
5 & $0.7 \%$ \\
0 & $0.0 \%$ \\
\hline 646 & $91.8 \%$
\end{tabular}

704 
Table 5: Summary of deny response options used: analysed by company (thematic analysis)

\begin{tabular}{|l|c|c|c|c|}
\hline & Total & BP & Transocean & Halliburton \\
\hline Shifting the blame / Scapegoating & 21 & 17 & 4 & 0 \\
\hline Attack / Accuse the accuser & 37 & 20 & 11 & 6 \\
\hline Simple denial & 26 & 4 & 15 & 7 \\
\hline Condemn the condemner & 2 & 0 & 2 & 0 \\
\hline
\end{tabular}


Figure 1: Response strategy

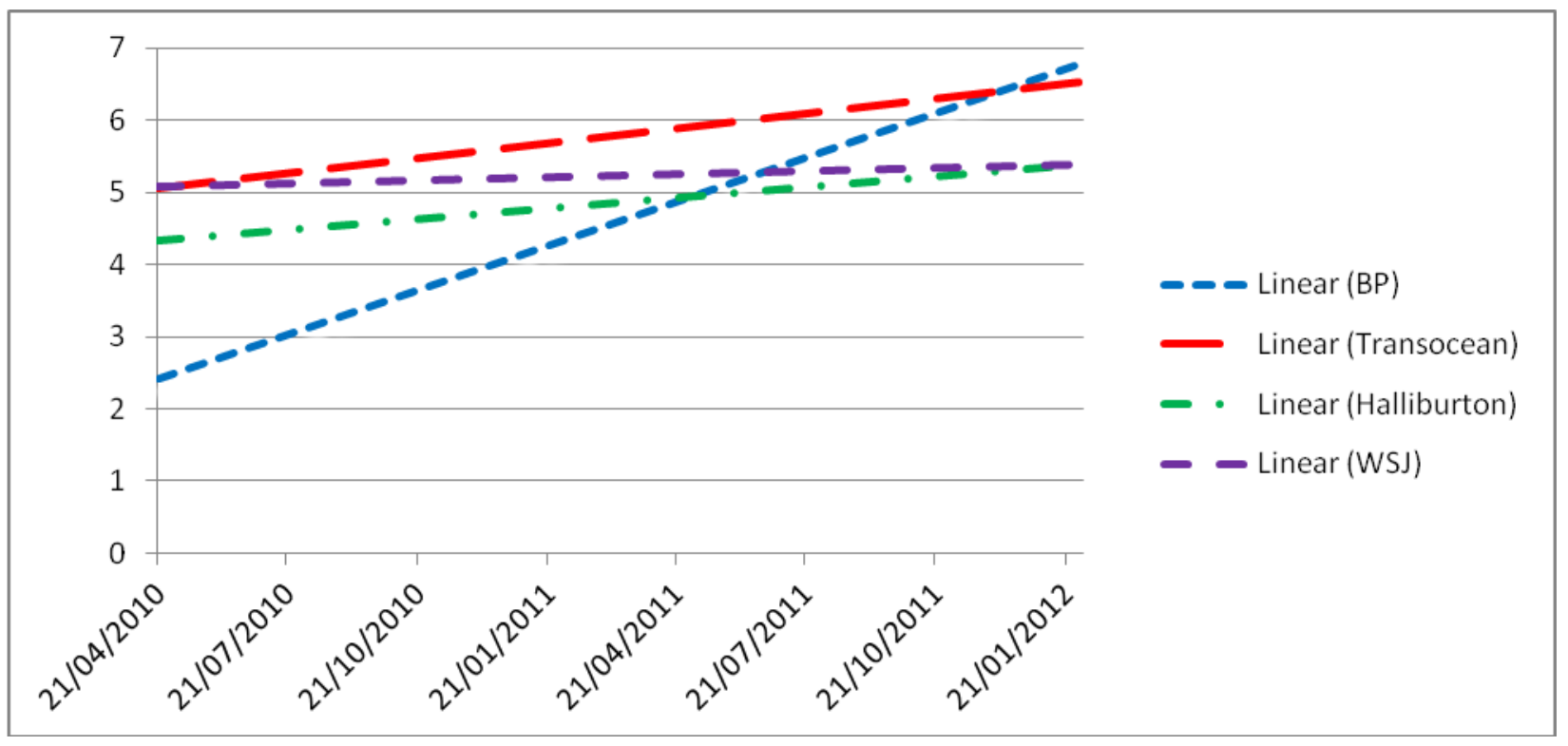

